\title{
Dr. Ashok Raj Koul (1962-2017)-My Recollections
}

\section{R. Srikanth ${ }^{1}$}

\author{
${ }^{1}$ Department of Plastic and Reconstructive Surgery, Nizam's \\ Institute of Medical Sciences, Hyderabad, Telangana, India
}

Indian J Plast Surg 2019;52:267-269

Dr. Ashok Raj Koul's journey started in Shopian, Kashmir (where he was born, - Fig. 1), and straddling across the length of the country he reached the zenith at the Sparsh Hospital, Bangalore (-Figs. 2 and 3). My interaction with him was once at his entry into the field of microsurgery and subsequently when he entered the field of brachial plexus injuries-a time frame of two decades.

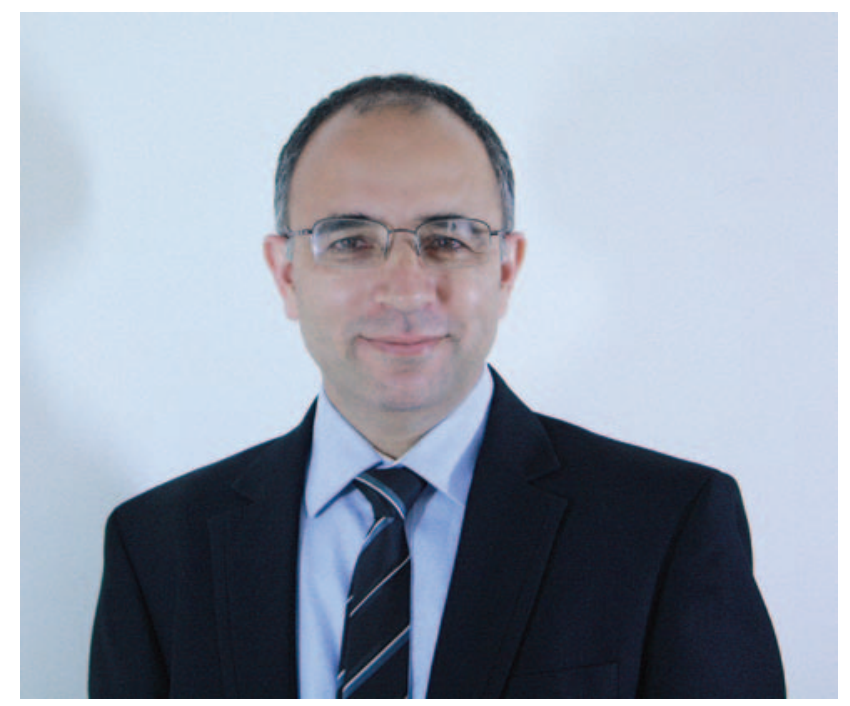

Fig. 1 Dr. Ashok Raj Koul.

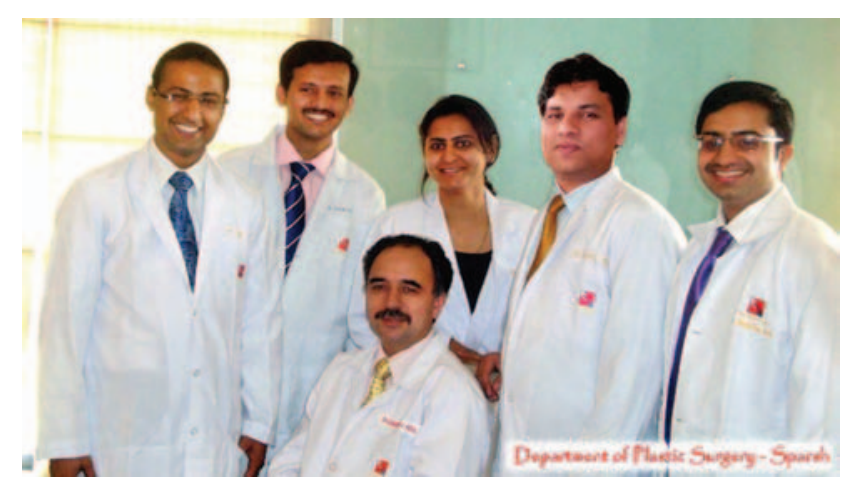

Fig. 2 At SPARSH Hospital, Bangalore.
Address for correspondence R. Srikanth, MCh (Plastic Surgery), Department of Plastic and Reconstructive Surgery, Nizam's Institute of Medical Sciences, Punjagutta, Hyderabad 500082, Telangana, India (e-mail: drsrikanthr@gmail.com).

Where do I start? Well ... right at the beginning. It was July 1995 and I had stepped into the MCh Plastic Surgery program at Post Graduate Institute of Medical Education and Research, Chandigarh ( - Fig. 4) and Dr. Ashok Koul was just leaving after graduating with his MCh degree. I heard him say to someone around, "I'm going to Hyderabad for getting my teeth into microsurgery."

Having taken the same decision myself in July 1997 and arriving at NIMS Hyderabad to work under Dr. Mukunda Reddy, I found I had just missed him (again!) and he had left to work on his own in Kochi ( - Fig. $\mathbf{5}$ ).

I did come to know about him from colleagues there in Hyderabad, as to how mentor and protégé had been pushing the field of microsurgery by walking way beyond the "trodden path" in reconstructive surgery (free latissimus dorsi muscle flaps for leg defects under tumescent and regional anesthesia, alternative pedicles for spilt illiac crest bone graft, second toe joint transfer for elbow reconstruction, and the like).

Microsurgery came easy to him probably because his surgical skills were inborn and that left him time to improvise and innovate on issues beyond the actual conduct of surgery (thus ensuring a synthesis of "nature and nurture").

I kept hearing accounts of his accomplishments at Kochi where he built up in microsurgery work, in quantity and quality and which came to all of us, in his scientific presentations and word of mouth from colleagues and students-the famed bilateral above elbow replantation, work on high voltage electrical burns, and the start of the idealized (or is it idolized!) "free groin flap" paradigm. The last being a sure sign of his accession to maturity ("donor site concern" being something he picked up during his stay in Hyderabad).

A quirk regarding presentations ... his presentations were always black and white (not literally) ... no grayscalesunembellished, to the point, leading to the heart of the matter, and hitting the audience with a thunderclap. He did tell me about his inability to weave any story into a scientific presentation-probably significant as the truth of any matter should not be diluted, adulterated with anything else (remember Nate Silver...the signal and the noise!)
DOI https://doi.org/

$10.1055 / \mathrm{s}-0039-3402828$

ISSN 0970-0358.
(C)2019 Association of Plastic Surgeons of India
License terms

(요 (1) $\Theta \circledast$ 


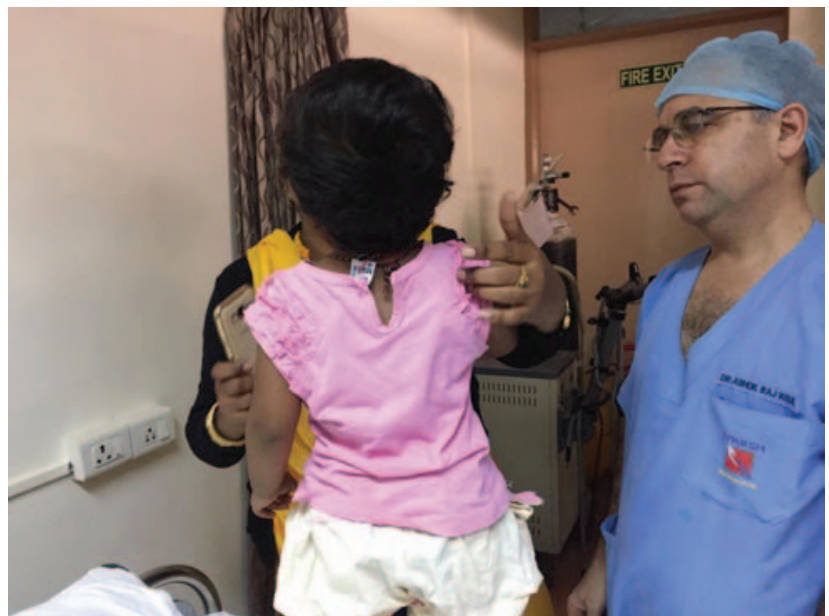

Fig. 3 Examining a child with brachial plexus injury.

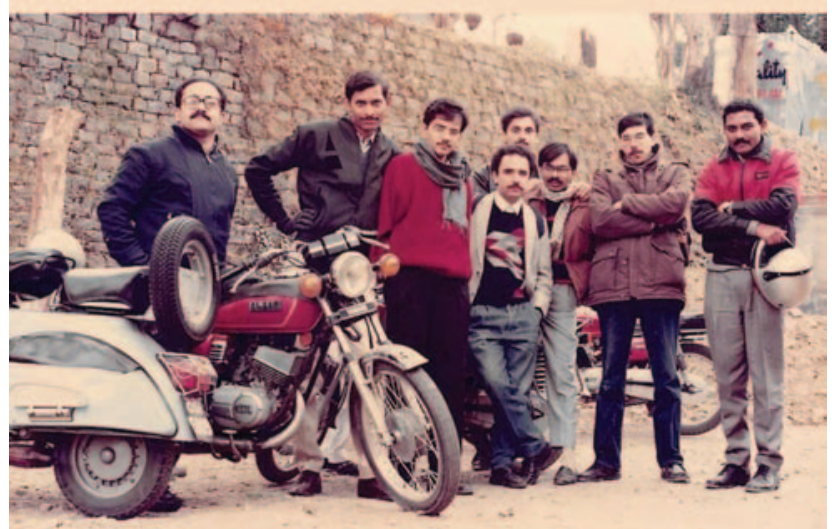

Fig. 4 At PGI, Chandigarh (1989-1992).

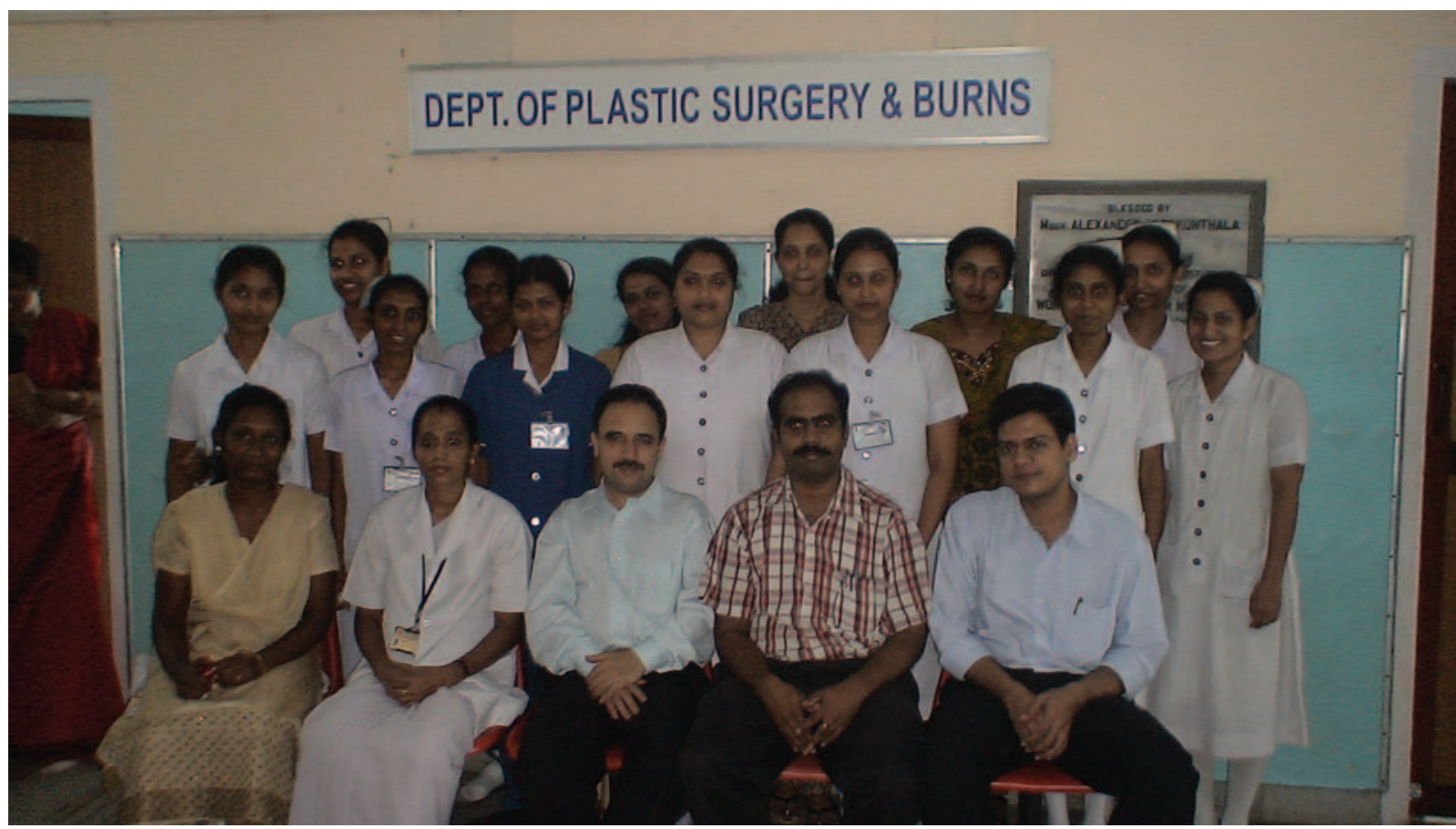

Fig. 5 Medical Trust Hospital Cochin, Kerala.

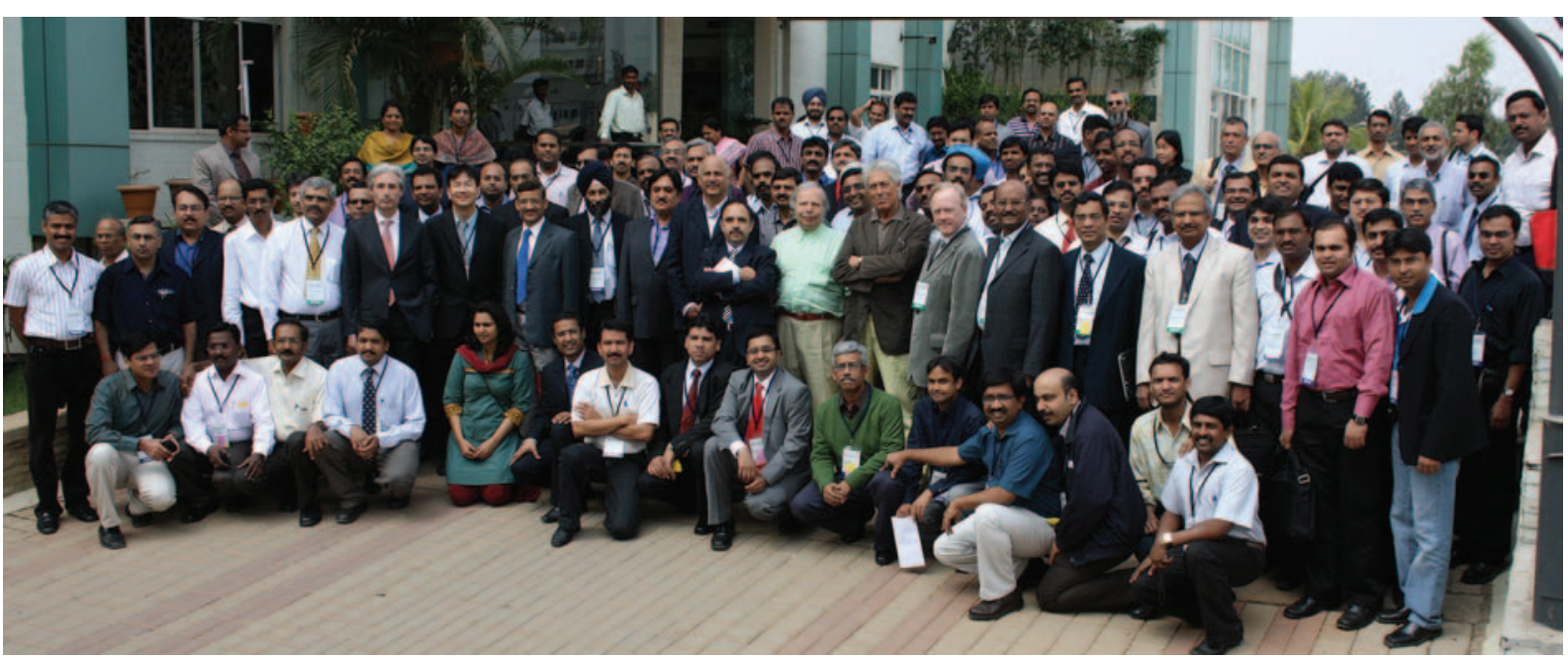

Fig. 6 Biennial meeting of Brachial Plexus Surgery Group of India, at Bangalore in 2011, organized by Dr. Ashok Koul. 


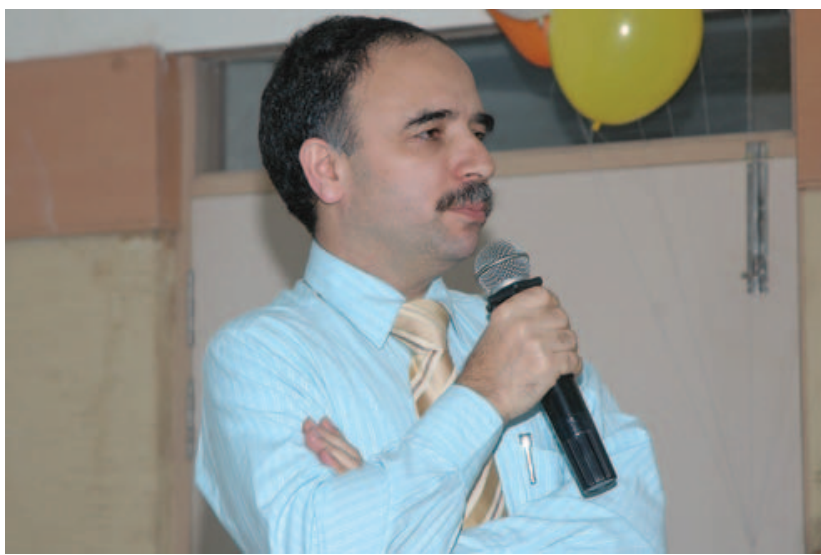

Fig. 7 Always made his presence felt with his active participation in presentations and discussions.

When we met midway during his tenure at Kochi, and chanced to discuss about "flow-through free flaps" he was derisive and did comment unfavorably about the same, stating that the indications for the same were very minimal-just on the strength of his expertise in end to side vascular anastomosis and the use of vein grafts for revascularization.

Quite sometime after that, and when I had a closer interaction with him, I realized the validity of his statement "anyone who can do a confident end to side anastomosis can probably be never 'caught short' in any type of free tissue transfer ...," something I have incorporated into my practice.

He fervently believed that vessel size in microsurgery was just a "mindset"; certainly he could press the "reset button" in his work with flair ... doing a free posterior interosseous flap, turning the local flap on its head! From there to "freestyle free flaps" -flaps sans "named vessels" was but just a step.

Somewhere along the line Dr. Ashok Koul became Koul or Ashok to me-the Brachialcon meeting at Bangalore ( - Fig. 6) when he advised me on setting a direction to my workquantity without quality in work was anathema to him.
Versatility was a keyword with Ashok-Albert Einstein had words for this--"Life is riding a bicycle ... to keep your balance, you must keep moving."

This mobility gave him the edge over others in tackling breast reconstruction, Volkman's ischemia, electrical burns, and brachial plexus injuries with equal flair.

If the work that men do lives after them then Ashok is way up in the stratosphere, on account of the "free groin flap," the "BERAM flap," and "freestyle free flaps."

On the education frontier, his students (Dr. Rahul Patil, Dr. Sushil Nahar, among others, ... are you listening?) swore by his teaching and training skills ( - Fig. 7). Certainly he has bequeathed a legacy to our specialty ... a proof of the work of a mortal man assured of immortality.

I was pleasantly surprised that he had a lighter side to him-he was addicted to Asterix series of comic books by Goscinny and Uderzo-as one, who has also spent time in the world of Obelix, Dogmatix, and Panacea, among others, I feel gratified to have rubbed shoulders with "HIM."

A tribute, if it has to come from me, can only be in the form of a song lyric and this I believe describes HIM to a "T":

...There's a mountain and it's mighty high You cannot see the top, unless you fly There's a molehill, of proven ground

There ain't nowhere to go if you hang around Everybody wants to sell what's already been sold Everybody wants to tell what's already been told What's the use of money (read knowledge instead) If you ain't gonna break the mold ...

Prince aka Rogers Nelson (the Gold song)

\section{Acknowledgment}

I would like to thank Dr. Dinesh Kadam for providing images for this article. 